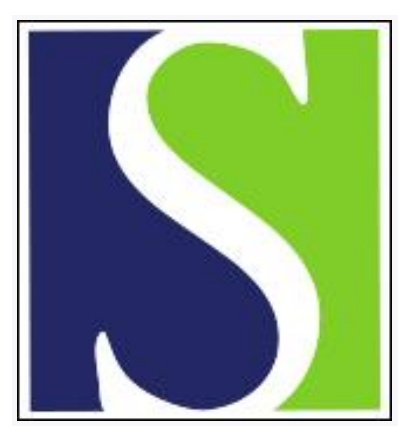

Scand J Work Environ Health 1976;2(2):71-81

https://doi.org/10.5271/sjweh.2816

Issue date: Jun 1976

Use of chlorophenols as fungicides in sawmills.

by Levin J-O, Rappe C, Nilsson C-A

Key terms: analytical toxicology; chlorodibenzodioxin; chlorodibenzofuran; chlorodipheynyl ehter; chlorophenol; chlorophenoxyphenol; fungicide; sawmill

This article in PubMed: www.ncbi.nlm.nih.gov/pubmed/959793

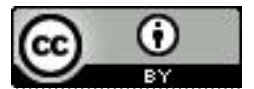




\title{
Use of chlorophenols as fungicides in sawmills
}

\author{
by JAN-OLOF LEVIN, Ph.D.,1, 2 CHRISTOFFER RAPPE, Ph.D. ${ }^{1}$, \\ and CARL-AXEL NILSSON, B.Sc. ${ }^{1,2}$
}

\begin{abstract}
LEVIN, J.-O., RAPPE, C. and NILSSON, C.-A. Use of chlorophenols as fungicides in sawmills. Scand. $j$. work environ. \& health 2 (1976) $71-81$. Several commercial formulations of chlorophenols used as fungicides in sawmills were found to contain impurities, some of which are known to be much more toxic than the main products. The most frequent impurities were chlorinated phenoxyphenols, chlorinated diphenyl ethers, chlorinated dibenzofurans, and chlorinated dibenzodioxins. Samples of wood dust from several positions in two Swedish sawmills were analyzed. The results suggest that the impurities in the chlorophenol formulations are enriched in the work environment in relation to the chlorophenols themselves, probably because of the low volatility and high chemical stability of the impurities. The effect of various methods of fungicide application on the work environment is discussed.
\end{abstract}

Key words: sawmill, analytical toxicology, fungicide, chlorophenol, chlorophenoxyphenol, chlorodibenzodioxin, chlorodibenzofuran, chlorodiphenyl ether.

When some kinds of timber - notably softwood species, such as pine - are felled and converted, they are susceptible to attack from stain and mold, particularly during the summer months. The most important kind of sap stain is the so-called blue stain. The causal fungi are principally Ceratostomella and Graphium.

Fungicide is applied to the green timber directly after sawing for the prevention of sap stain. The most widely used fungicides are salts of chlorophenols,

1 Department of Organic Chemistry, University of Umeå, Umeå, Sweden.

2 Present address: National Board of Occupational Safety and Health, Occupational Health Department, Chemical Unit, Umeå, Sweden.

Reprint requests to: Dr. Jan-Olof Levin, National Board of Occupational Safety and Health, Occupational Health Department, Chemical Unit at Umeå, S-901 85 Umeå, Sweden. which are applied as aqueous solutions containing approximately $1 \%$ of the sodium or potassium salt. The most common method of application is dipping. Bundles of sawn timber are lowered into a tank containing the chlorophenate solution and then kept submerged for 15 to $20 \mathrm{~s}$. The wood is then allowed to dry. Sawmills using kiln drying often apply the chlorophenate solution by spray treatment in the kiln before drying.

The use of chlorophenols in sawmills is known to cause occupational health problems. In an investigation carried out by Levin (11), it was noted that the workers in the trimming-grading plant, where the sawn timber is handled after chlorophenol treatment and drying, often complain of cutaneous irritations, respiratory difficulties, headache, etc. Several serious intoxications connected with the use of chlorophenols in sawmills are reported in the literature. For example, 
Truhaut et al. (22) reported occupational intoxication from pentachlorophenol, which afflicted men dipping planks of wood in a $3 \%$ solution of a mixture containing $80 \%$ sodium pentachlorophenate and $20 \%$ sodium tetrachlorophenate. Some workers showed only cutaneous symptoms; others showed symptoms of anesthesia, loss of appetite, and respiratory difficulties. The urine contained 3 to $10 \mathrm{mg}$ of pentachlorophenol per liter. Case histories of two workmen with a fatal outcome were presented. Menon (12) described the death of nine native workers who had been handling dripping-wet timber, freshly treated with sodium pentachlorophenate in a Borneo sawmill.

\section{CHEMISTRY AND TOXICOLOGY OF CHLOROPHENOLS}

Commercial chlorophenol formulations intended for use as fungicides are normally sodium or potassium salts containing three to five chlorine atoms. The most widely used formulation in Sweden is the sodium salt of a 2,3,4,6-tetrachlorophenol.

Mast chlorophenol formulations contain a number of chlorinated impurities of higher molecular weight $(2,4,7,15,17$, 18). The most frequent types are shown in fig. 1 .

The toxicological situation is extremely complicated. Single oral $\mathrm{LD}_{50}$ values for chlorophenol formulations range from about 200 to about $800 \mathrm{mg} / \mathrm{kg}$ of body weight for rats. The lower chlorinated formulations have higher $\mathrm{LD}_{50}$ values. The long-term effects of chlorophenols are unknown.

In man, chlorinated aromatics like chlorophenols are known to produce chloracne $(3,21)$. A number of serious outbreaks of chloracne linked with the production of chlorophenols has been reported in the literature. In 1972 Goldmann (5) reported a very severe outbreak of chloracne in connection with an accident arising from an unforeseen chemical reaction in a plant manufacturing 2,4, 5-trichlorophenol. Detailed occupational and case histories were reported. It was found that 2,3,7,8-tetrachlorodibenzodioxin
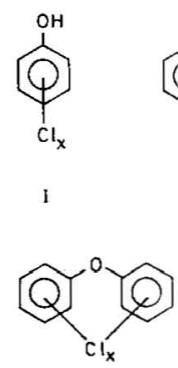

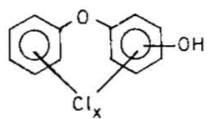

$1 !$

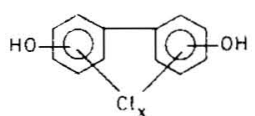

III
Fig. 1. Constituents of commercial chlorophenol formulations. I: polychlorophenols; II: polychlorophenoxyphenols; III: polychlorodihydroxybiphenyls; IV: polychlorodiphenyl ethers; V: polychlorodibenzofurans; VI: polychlorodibenzodioxins.

was the toxic causative for skin changes in a total of 42 serious cases, 14 persons suffering consequent damage to internal organs and 7 persons experiencing disturbances in the nervous system. In 1957 Kimming and Schulz (10) established for the first time the elementary but vital fact that, whereas crude commercial 2,4,5trichlorophenol had an acnegenic effect on the inner side of the rabbit ear, purified 2,4,5-trichlorophenol did not. Thus there seems little reason to doubt that chloracne is produced by chlorodibenzodioxins or similar substances present as impurities in crude commercial chlorophenol formulations.

Certain chlorodibenzodioxins are highly toxic compounds (9) and 2,3,7,8-tetrachlorodibenzodioxin - a contaminant of 2,4,5-trichlorophenol - is one of the most toxic chemicals known. Single oral $\mathrm{LD}_{50}$ values for male guinea pigs are about $1 \mu \mathrm{g} / \mathrm{kg}$ of body weight (9). The compound is strongly acnegenic (8), teratogenic (20), embryotoxic (13), and mutagenic (6) and has been shown to supress cellular immunity in rats and mice (24). On the other hand, $2.0 \mathrm{~g} / \mathrm{kg}$ and $4.0 \mathrm{~g} / \mathrm{kg}$ of body weight of 2,7-dichlorodibenzodioxin and octachlorodibenzodioxin, respectively, are not lethal to rats (19).

Not much is known about the toxicity of chlorodibenzofurans. Vos et al. (23) reported that the toxicity of certain chlorodibenzofurans is similar to that of the dioxins. Zitko and Choi (25) reported that chlorodibenzofurans are very toxic to juvenile Atlantic salmon. 
Practically nothing is known about the toxicity of chlorophenoxyphenols and chlorodiphenyl ethers. However Nilsson et al. found that photolysis and pyrolysis of chloro-2-phenoxyphenols yield chlorodibenzodioxins (14). (See scheme 1.) Norström et al. (16) reported that photolysis of certain chlorodiphenyl ethers results in the formation of chlorodibenzofurans. (See scheme 2.)
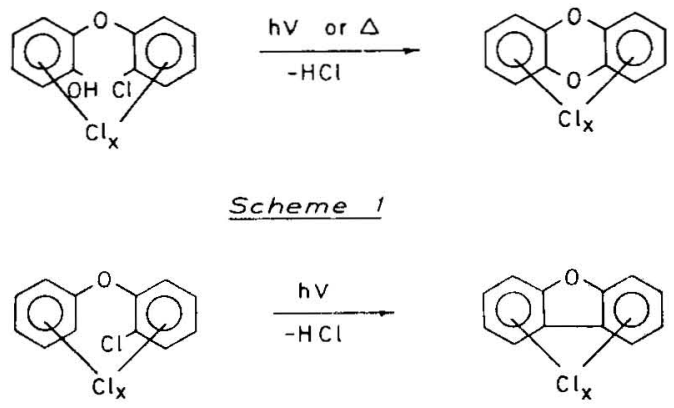

Scheme
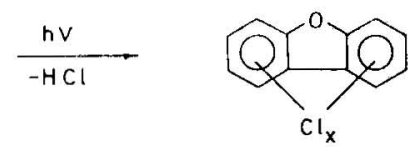

Scheme?

\section{MATERIAL AND METHODS}

Identification of impurities in commercial chlorophenol formulations

As previously mentioned, many contaminants have been identified in chlorophenols. Some of these are shown in fig. 1. Both extraction and chromatographic methods, as well as combinations of them, have been used for the separation of different impurities. $(2,4,7,15,17,18)$. In the present case we employed thin-layer chromatography (TLC) to achieve gross separation between different types of compounds and followed it with a gas chromatographic-mass spectrometric (GC-MS) analysis for the identification of individual components.

An acidified chlorophenate solution was extracted with ether (p.a.), and the ethereal solution applied to a $20 \times 20-\mathrm{cm}$ precoated TLC plate (Merck's DC-Fertigplatten Kiselgel $60 \quad \mathrm{~F}_{254}, 0.25-\mathrm{mm}$ layer). The chromatogram was developed with chloroform and made visible under ultraviolet light $(254 \mathrm{~nm})$. The chromatogram is shown in fig. 2. Three bands were scraped off, eluted with acetone (p.a.), and submitted to GC-MS analysis (LKB 9000 mass spectrometer equipped with a PyeUnicam, model 84, gas chromatograph and a split to a flame ionization detector). Band $1(\mathrm{Rf}=0.2-0.4)$ consisted of chlorophenols. Band $2(\mathrm{Rf}=0.4-0.5)$ consisted of chlorophenoxyphenols, and band 3 (Rf $=0.6-0.7)$ consisted of neutral components, i.e., chlorodiphenyl ethers, chlorodibenzodioxins, and chlorodibenzofurans.

Quantification of impurities in commercial chlorophenol formulations

The preceding separation procedure was employed. The chlorophenate formulation $(0.50 \mathrm{~g})$ was dissolved in $10.0 \mathrm{ml}$ of water. The solution was acidified with 2 $M$ sulfuric acid and extracted with ether (p.a.). The ethereal phase was washed with water and evaporated to dryness. The residue was dissolved in $10.0 \mathrm{ml}$ of acetone (p.a.). Ten to fifty $\mu 1$ of this solution was applied to a $5 \times 20$-cm precoated TLC plate, and the chromatogram was developed with chloroform. Bands 2 (chlorophenoxyphenols) and 3 (neutral components) were scraped off and shaken with $1.0 \mathrm{ml}$ of hexane (p.a.), and band 2 was methylated with diazomethane. The solutions were then submitted to gas chromatographic analysis. [Pye-Unicam model 84 gas chromatograph, equipped with a $\mathrm{Ni}^{63}$ electron-capture (EC) detector].

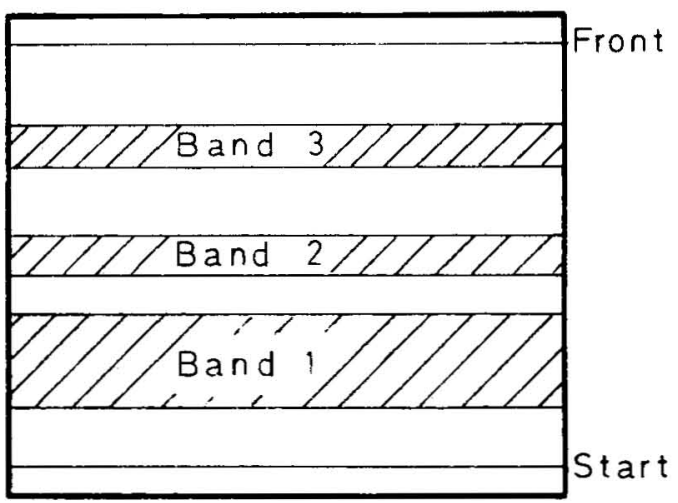

Fig. 2. Thin-layer chromatogram of the acidified chlorophenol formulation eluted with chloroform. 


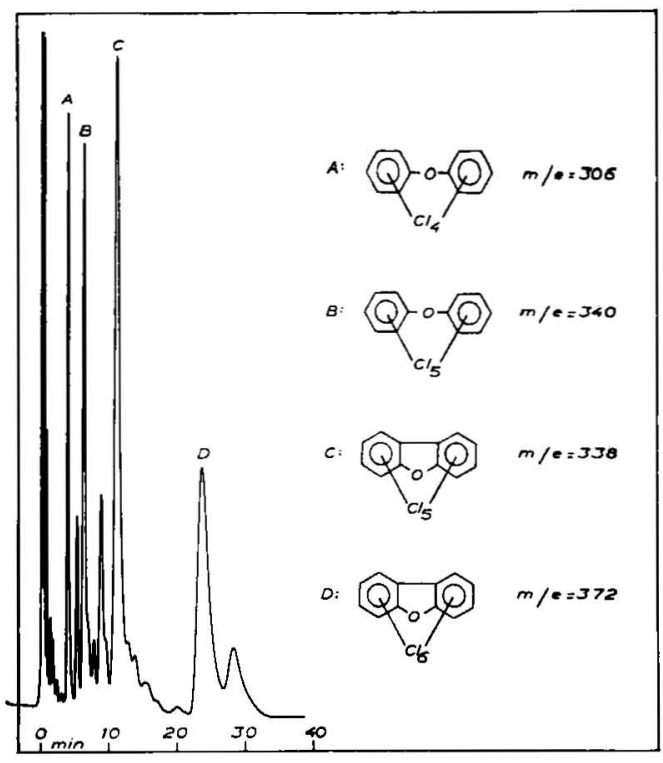

Fig. 3. Electron-capture gas chromatogram of neutral components in a commercial 2,4,6trichlorophenol formulation (Column temperature $210^{\circ} \mathrm{C}$ ).

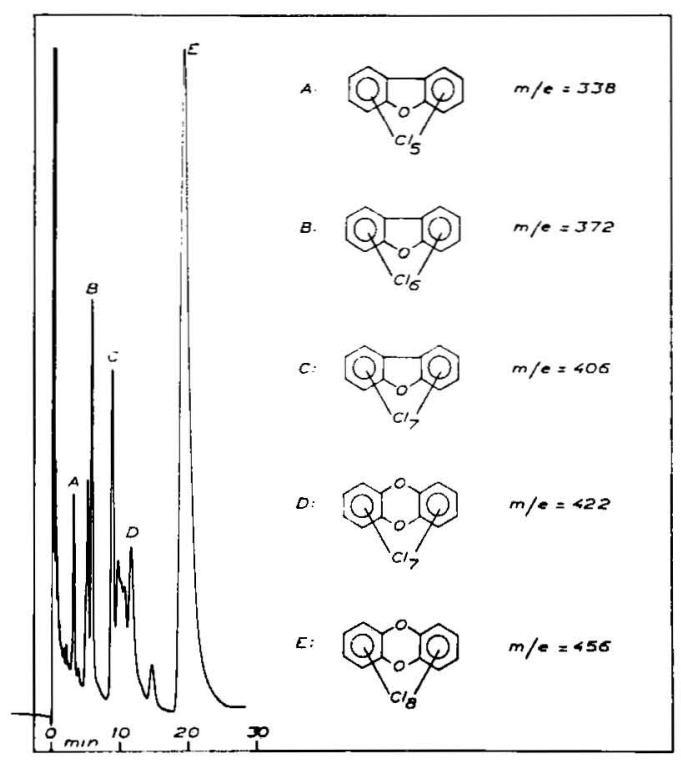

Fig. 5. Electron-capture gas chromatogram of neutral components in a commercial pentachlorophenol formulation (Column temperature $\left.240^{\circ} \mathrm{C}\right)$.

The column was a glass column, $1.7 \mathrm{~m}$, ID $0.40 \mathrm{~cm}$, filled with $1 \% \mathrm{OV}-17$ on acid-washed, dimethyldichlorosilane-treated Chromosorb W (100-120 mesh). The

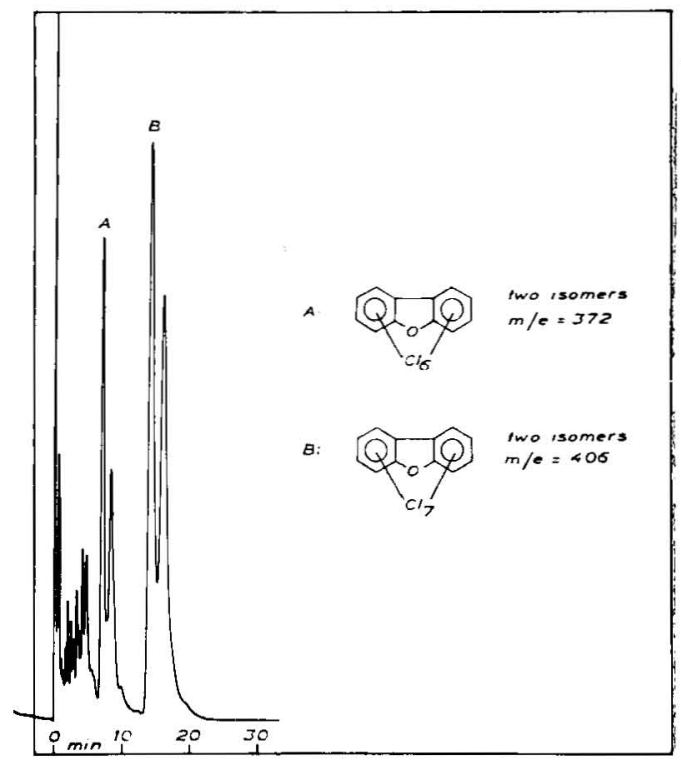

Fig. 4. Electron-capture gas chromatogram of neutral components in a commercial 2,3,4,6tetrachlorophenol formulation (Column temperature $230^{\circ} \mathrm{C}$ ).

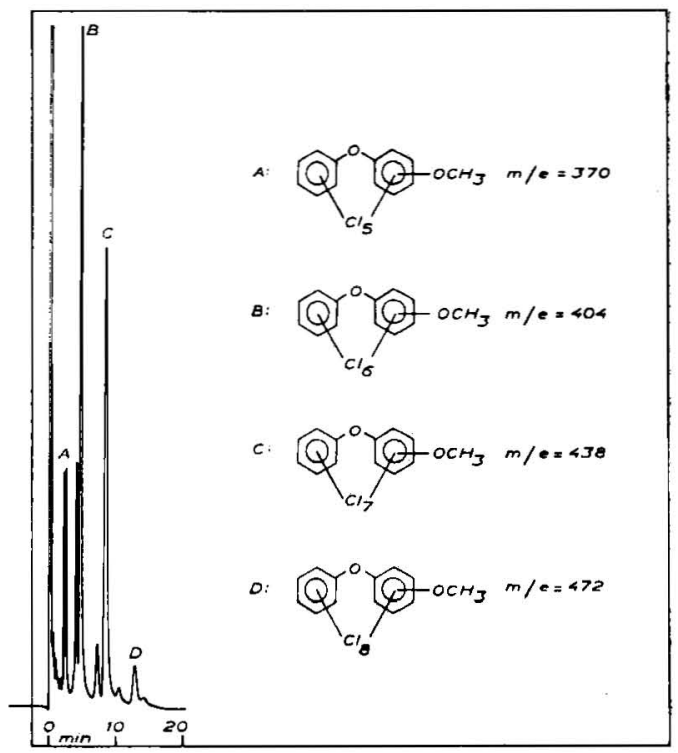

Fig. 6. Electron-capture gas chromatogram of phenoxyphenols (methylated) in a commercial 2,3,4,6-tetrachlorophenol formulation (Column temperature $230^{\circ} \mathrm{C}$ ).

operation conditions were: injection temperature $275^{\circ} \mathrm{C}$, column temperature 220 $240^{\circ} \mathrm{C}$, detector temperature $250^{\circ} \mathrm{C}$, carrier gas nitrogen $(40 \mathrm{ml} / \mathrm{min})$. 
The standards used were pentachloro2-phenoxyphenol (methyl ether), tetrachlorodibenzodioxin, pentachlorodibenzodioxin, octachlorodibenzodioxin, tetrachlorodibenzofuran, tetrachlorodiphenyl ether, and pentachlorodiphenyl ether. As all compounds present as impurities in the chlorophenol formulations were not available as standards, the levels quoted in the tables are approximate.

In figs. 3-5 electron-capture gas chromatograms (EC-GCs) of neutral compo- nents in three commercial chlorophenol formulations are shown. Fig. 6 presents the EC-GC of the methylated phenoxyphenol band from a 2,3,4,6-tetrachlorophenol formulation.

Sampling and analysis of wood dust from sawmills

Information requested from the Swedish Labor Inspectorate and from Swedish sawmill owners (11) shows that the occu-

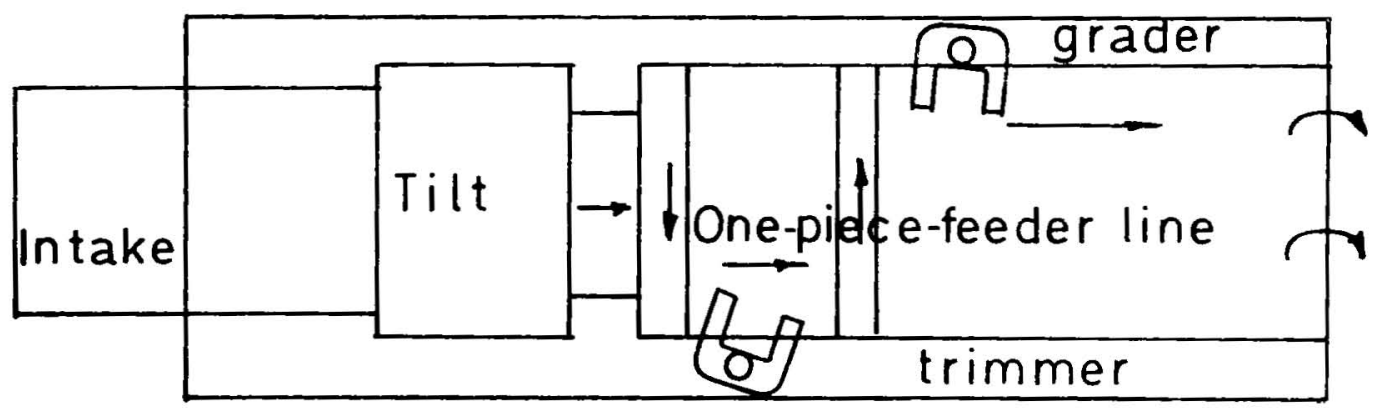

Fig. 7. Trimming-grading plant of a sawmill. Packaging is located in a plane beneath the one-piece-feeder line.

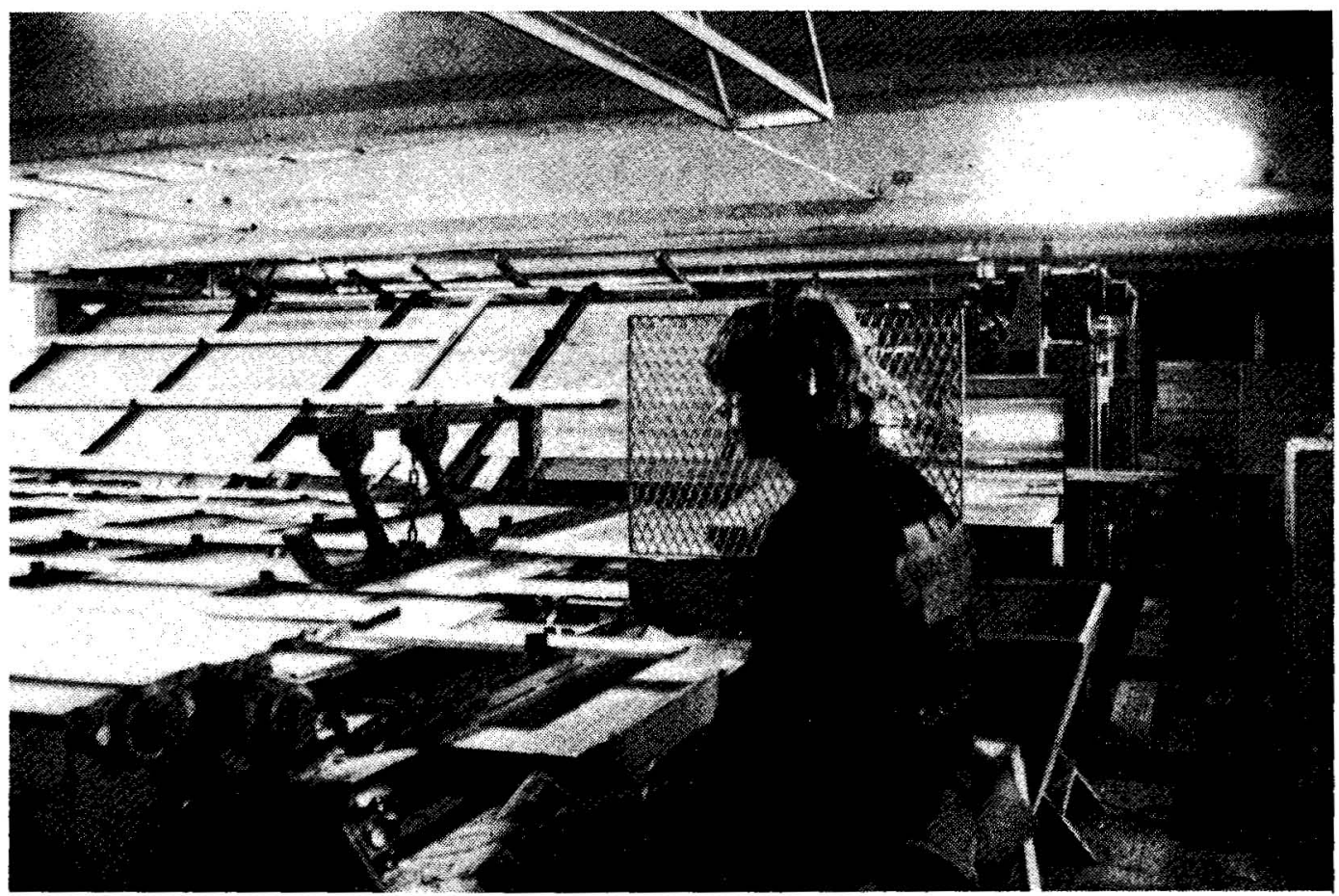

Fig. 8. Butt-end trimmer in a trimming-grading plant. 


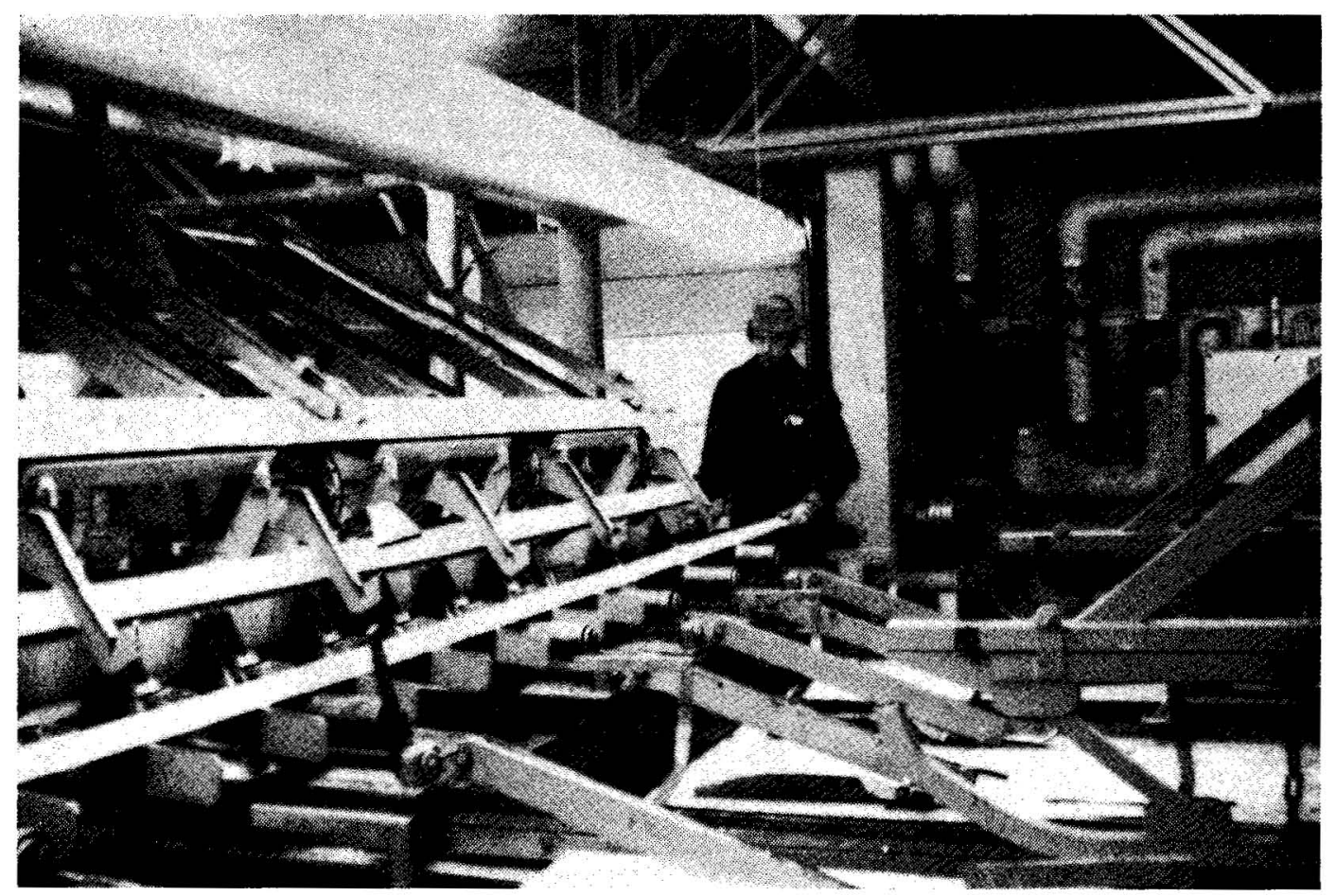

Fig. 9. Grader in a trimming-grading plant.

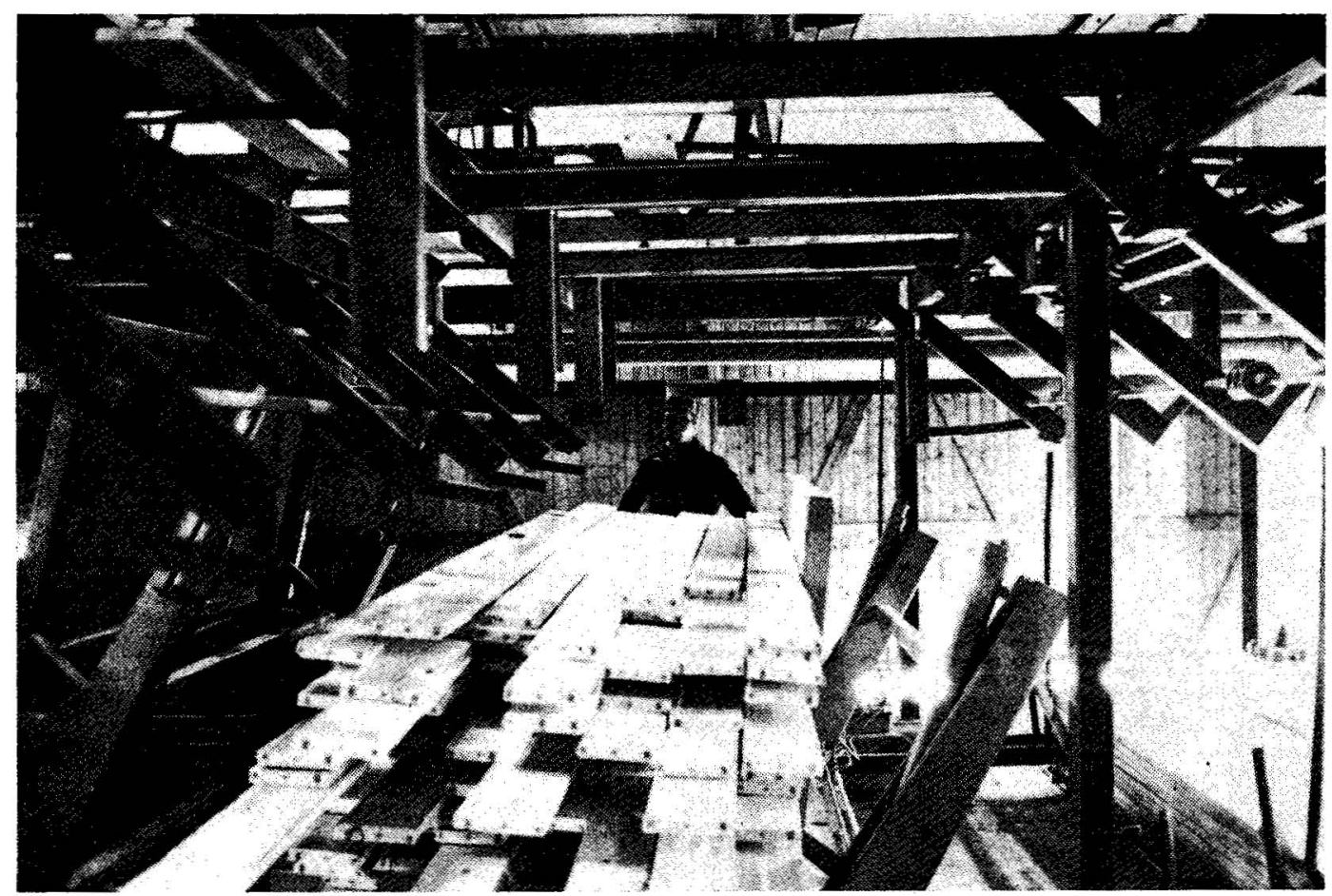

Fig. 10. Packager in a trimming-grading plant. 


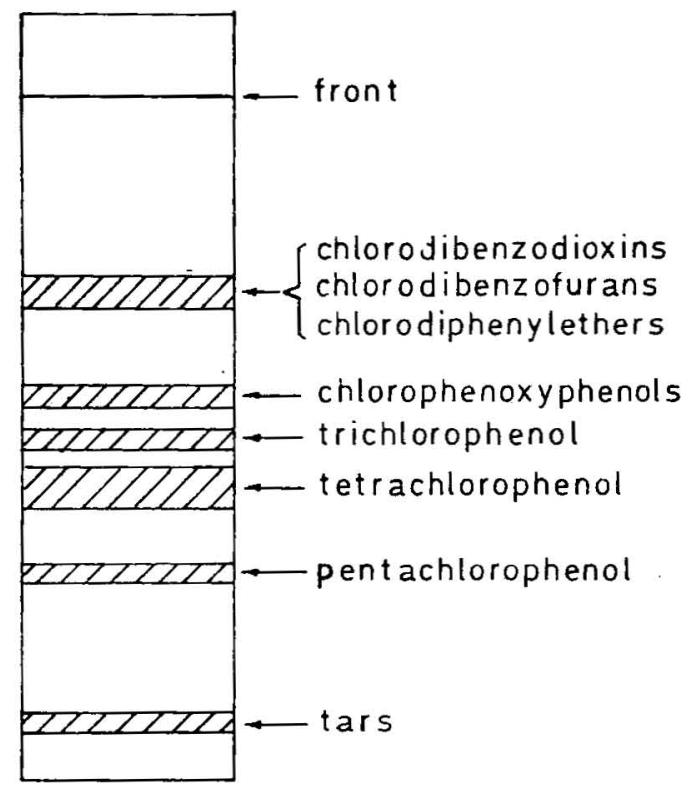

Fig. 11. Thin-layer chromatogram of wooddust extract eluated with chloroform.

pational health problems associated with the use of chlorophenols are mostly confined to the trimming-grading plant of the sawmill. There the sawn and dried wood is handled for the first time after chlorophenol treatment, and it is likely that the wood dust emitted contains some chlorophenol. The trimming-grading plant (fig. 7) is operated by a butt-end trimmer (fig. 8) and one or several graders (fig. 9). The sawn timber is packaged after grading. Packaging is often located underneath the one-piece-feeder line (fig. 10) in the trimming-grading plant.

Wood dust from the three work positions, trimming, grading and packaging, was collected and analyzed. The following procedure was employed: 1 to $5 \mathrm{~g}$ of wood dust was extracted with ether (p.a.) in a Soxhlet apparatus overnight. The ether was evaporated, and the tarry residue was dissolved in $5.0 \mathrm{ml}$ of acetone (p.a.). Thirty to sixty $\mu \mathrm{l}$ of this solution was applied to a $5 \times 20-\mathrm{cm}$ precoated TLC plate, and the chromatogram was developed with chloroform. The resulting chromatogram is shown in fig. 11. The bands were scraped off and analyzed as described earlier. The phenolic compounds were analyzed as their methyl ethers.
In fig. 12 the EC-GC of the neutral component band from the sawdust extract is shown, and fig. 13 presents the ECGC of the methylated phenoxyphenol band.

Wood-dust exposure measurements were carried out in the trimming-grading plant of two sawmills in northern Sweden. Measurements were taken for 3 days at each sawmill, and personal sampling pumps were worn by workers in the trimming, grading, and packaging positions. After the dust filters were weighed, the dust was extracted and analyzed in the same way as described previously. Because

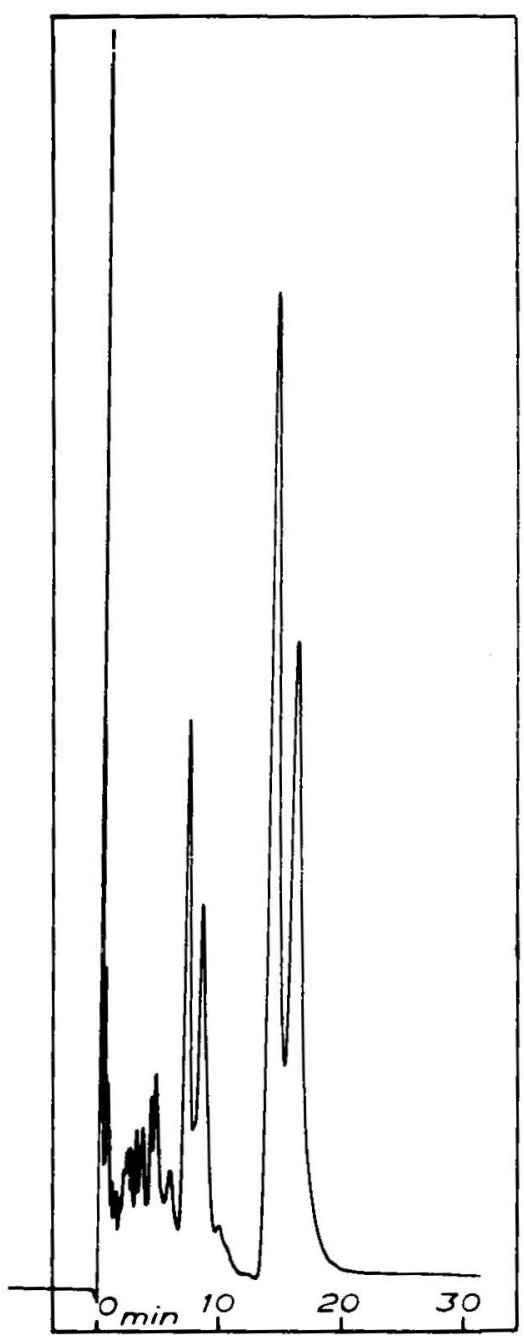

Fig. 12. Electron-capture gas chromatogram of neutral chlorinated components in sawdust (cf. fig. 4). 


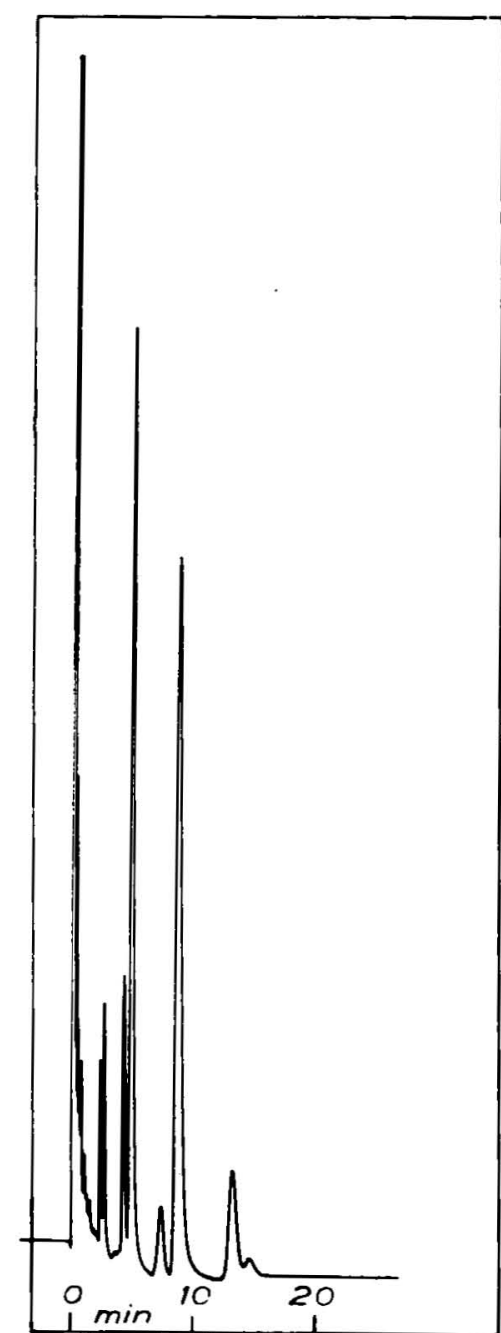

Fig. 13. Electron-capture gas chromatogram of chlorophenoxyphenols (methylated) in sawdust (cf. fig. 6).

of the small amount of dust on each filter (1-2 mg), only the chlorophenol content was determined.

Personal sampling pumps with charcoal tubes were used to check for chlorophenols dissolved in the air. Tetrachlorophenol levels in air were less than $0.001 \mathrm{mg} / \mathrm{m}^{3}$.

\section{RESULTS AND DISCUSSION}

Table 1 presents the levels of different impurities in three commercial chlorophenol formulations widely used as fungicides in Swedish sawmills.
Not many quantitative determinations of different contaminants in chlorophenols have been reported in the literature. Using electron-capture gas chromatography, Firestone et al. (4) estimated the chlorodibenzodioxin content in 21 commercial chlorophenols. Using mass fragmentography, Buser (2) determined the chlorodibenzodioxin and chlorodibenzofuran content of two commercial chlorophenols, one tetrachloro- and one pentachlorophenol. The tetrachlorophenol formulation contained approximately $100 \mathrm{ppm}$ of chlorodibenzodioxins $\left(\mathrm{Cl}_{7}, \mathrm{Cl}_{8}\right)$ and $900 \mathrm{ppm}$ of chlorodibenzofurans $\left(\mathrm{Cl}_{6}, \mathrm{Cl}_{7}, \mathrm{Cl}_{8}\right)$; and the pentachlorophenol, $500 \mathrm{ppm}$ of chlorodibenzodioxins $\left(\mathrm{Cl}_{7}, \mathrm{Cl}_{8}\right)$ and $500 \mathrm{ppm}$ of chlorodibenzofurans $\left(\mathrm{Cl}_{7}, \mathrm{Cl}_{8}\right)$. Nilsson and Renberg (15) and Jensen and Renberg (7) have studied the chlorophenoxyphenol content of commercial chlorophenols. According to these authors some formulations contain up to $5 \%$ of chlorophenoxyphenols.

Very few determinations of chlorophenol contaminants in the environment can be found in the literature. One exception is the determination of the highly toxic substance 2,3,7,8-tetrachlorodibenzodioxin, which can be detected at the ppt level (1). It should be noted that $2,3,7,8-$ tetrachlorodibenzodioxin is a contaminant of 2,4,5-trichlorophenol, a substance not used as a fungicide in sawmills.

Table 2 presents the results of analyses of sawdust samples collected from the trimming, grading, and packaging positions of a sawmill using the tetrachlorophenol formulation described in table 1 . The solution is applied by means of spray treatment in the kiln, the treatment being continued the whole year round (sawmill A). As can be seen from table 2, there is an enrichment of chlorodibenzofurans in the sawdust in relation to the chlorophenol content, when compared to that in the fungicide used. In the chlorophenol formulation the ratio tetrachlorophenol:chlorodibenzofurans is approximately 10,000:1; and in the sawdust, approximately $100: 1$. It can also be seen from table 2 that the highest contaminant levels are found at the beginning of the feeder line.

Table 3 presents the results of analyses of sawdust from a sawmill using dipping as the method of application (sawmill B). 
Table 1. Approximate quantities of certain impurities in three commercial chlorophenol formulations used as fungicides in Swedish sawmills.

\begin{tabular}{|c|c|c|c|c|c|c|}
\hline Formulation & $\begin{array}{l}\text { Main } \\
\text { products }\end{array}$ & $\begin{array}{l}\text { Chlorophen- } \\
\text { oxyphenols } \\
\text { (ppm) }\end{array}$ & $\begin{array}{l}\text { Chlorodi- } \\
\text { benzofurans } \\
\text { (ppm) }\end{array}$ & $\begin{array}{l}\text { Chlorodi- } \\
\text { benzo- } \\
\text { dioxins } \\
(\mathrm{ppm})\end{array}$ & $\begin{array}{l}\text { Chlorodi- } \\
\text { phenyl } \\
\text { ethers } \\
\text { (ppm) }\end{array}$ & Fig. \\
\hline $\begin{array}{l}\text { Potassium } \\
\text { salt of } 2,4,6- \\
\text { trichloro- } \\
\text { phenol } \\
\text { (water } \\
\text { solution) }\end{array}$ & $\begin{array}{l}\mathrm{Cl}_{3} \text {-phenol } \\
(55 \%) \\
\mathrm{Cl}_{4} \text {-phenol } \\
(5 \%)\end{array}$ & $\begin{array}{l}2,000-5,000 \\
\left(\mathrm{Cl}_{4}, \mathrm{Cl}_{5}, \mathrm{Cl}_{6}\right)\end{array}$ & $\begin{array}{l}100-200 \\
\left(\mathrm{Cl}_{5}, \mathrm{Cl}_{6}\right)\end{array}$ & $<1$ & $\begin{array}{l}50-100 \\
\left(\mathrm{Cl}_{4}, \mathrm{Cl}_{5}, \mathrm{Cl}_{6}\right)\end{array}$ & 3 \\
\hline $\begin{array}{l}\text { Sodium salt } \\
\text { of } 2,3,4,6- \\
\text { tetrachloro- } \\
\text { phenol }\end{array}$ & $\begin{array}{l}\mathrm{Cl}_{3} \text {-phenol } \\
(5 \% \%) \\
\mathrm{Cl}_{4} \text {-phenol } \\
(50 \%) \\
\mathrm{Cl}_{5} \text {-phenol } \\
(10 \%)\end{array}$ & $\begin{array}{l}2,000-5,000 \\
\left(\mathrm{Cl}_{5}, \mathrm{Cl}_{6}, \mathrm{Cl}_{7}, \mathrm{Cl}_{8}\right)\end{array}$ & $\begin{array}{l}70-150 \\
\left(\mathrm{Cl}_{6}, \mathrm{Cl}_{7}\right)\end{array}$ & $1-5$ & $\begin{array}{l}5-10 \\
\left(\mathrm{Cl}_{5}, \mathrm{Cl}_{6}, \mathrm{Cl}_{7}\right)\end{array}$ & 4,6 \\
\hline $\begin{array}{l}\text { Sodium salt } \\
\text { of penta- } \\
\text { chlorophenol }\end{array}$ & $\begin{array}{l}\mathrm{Cl}_{4} \text {-phenol } \\
(5 \% \%) \\
\mathrm{Cl}_{5} \text {-phenol } \\
(90 \%)\end{array}$ & $\begin{array}{l}2,000-5,000 \\
(>90 \% \text { Clg })\end{array}$ & $\begin{array}{l}100-300 \\
\left(\mathrm{Cl}_{5}, \mathrm{Cl}_{6}, \mathrm{Cl}_{7}\right)\end{array}$ & $\begin{array}{l}500-2,000 \\
\left(\mathrm{Cl}_{7}, \mathrm{Cl}_{8}\right)\end{array}$ & $\begin{array}{l}5-10 \\
\left(\mathrm{Cl}_{8}, \mathrm{Cl}_{9}\right)\end{array}$ & 5 \\
\hline
\end{tabular}

Table 2. Chlorinated contaminants in sawdust from a trimming-grading plant (sawmill A).

\begin{tabular}{lccc}
\hline Position & $\begin{array}{c}\mathrm{Cl}_{4-} \\
\text { phenol } \\
(\mathrm{ppm})\end{array}$ & $\begin{array}{c}\text { Chloro- } \\
\text { phenoxy- } \\
\text { phenols } \\
(\mathrm{ppm})\end{array}$ & $\begin{array}{c}\text { Chlorodi- } \\
\text { benzo- } \\
\text { furans } \\
\text { (ppm) }\end{array}$ \\
\hline Trimming & 300 & 30 & 6 \\
Grading & 100 & 10 & 3 \\
Packaging & 70 & 10 & 1 \\
\hline
\end{tabular}

The same chlorophenol formulation as in sawmill $A$ is used. In this case no enrichment of chlorodibenzofurans in the sawdust can be seen, but as in the previous case the sawdust of the trimming position has the highest chlorophenol content.

When dipping is employed, a sludge of sawdust collects on the bottom of the dipping tank. Samples of this sludge were dried and analyzed. The results are shown in table 4. As can be seen from the table, the sludge is remarkably enriched with chlorinated dibenzofurans. The chlorodibenzofuran content in the sludge is about ten times higher than that in the chlorofenol formulation used. (See table 1.)

The solubility of chlorinated dibenzodioxins and dibenzofurans in water is extremely low. Thus these compounds
Table 3. Chlorinated contaminants in sawdust from a trimming-grading plant (sawmill B).

\begin{tabular}{lccc}
\hline Position & $\begin{array}{c}\mathrm{Cl}_{4-} \\
\text { phenol } \\
(\mathrm{ppm})\end{array}$ & $\begin{array}{c}\text { Chloro- } \\
\text { phenoxy- } \\
\text { phenols } \\
\text { (ppm) }\end{array}$ & $\begin{array}{c}\text { Chlorodi- } \\
\text { benzo- } \\
\text { furans } \\
\text { (ppm) }\end{array}$ \\
\hline Trimming & 450 & 13 & $<0.5$ \\
Grading & 50 & 8 & $<0.5$ \\
Packaging & 125 & 15 & $<0.5$ \\
\hline
\end{tabular}

Table 4. ChIorinated contaminants in sludge from the dipping tank (sawmill B).

\begin{tabular}{lcc}
\hline $\begin{array}{l}\mathrm{Cl}_{4} \text {-phenol } \\
(\%)\end{array}$ & $\begin{array}{c}\text { Chlorophen- } \\
\text { oxyphenols } \\
(\mathrm{ppm})\end{array}$ & $\begin{array}{c}\text { Chlorodi- } \\
\text { benzofurans } \\
(\mathrm{ppm})\end{array}$ \\
\hline 2.5 & 200 & 700 \\
\hline
\end{tabular}

will precipitate from the dipping solution, and the bottom sludge of the dipping tank will be highly contaminated with chlorodibenzodioxins and dibenzofurans. Consequently the levels of chlorodibenzofurans in the sawdust from the trimming-grading plant will be low. Therefore the dipping method of application is preferable, provided that the highly contaminated sludge of the dipping tank can be disposed of in a satisfactory manner. 
Table 5. Levels of sawdust in a trimminggrading plant (sawmill B).

\begin{tabular}{lccc}
\hline Position & $\begin{array}{c}\text { Levels } \\
\text { of } \\
\text { sawdust } \\
\left(\mathrm{mg} / \mathrm{m}^{3}\right)\end{array}$ & $\begin{array}{c}\mathrm{Cl}_{4} \text {-phenol } \\
\text { in } \\
\text { sawdust } \\
(\mathrm{ppm})\end{array}$ & $\begin{array}{c}\text { Levels } \\
\text { of } \\
\mathrm{Cl}_{4} \text {-phenol } \\
\left(\mathrm{mg} / \mathrm{m}^{3}\right)\end{array}$ \\
\hline Trimming & 2.0 & 800 & 0.0016 \\
Grading & 1.4 & 70 & 0.0001 \\
Packaging & 1.5 & 20 & 0.00003 \\
\hline
\end{tabular}

In addition gas chromatographic analyses of sawdust from the kiln suggest that chlorodibenzodioxins may be formed under drying conditions (i.e., $40-50^{\circ} \mathrm{C}$ for a prolonged time), probably according to scheme 1. These substances will make the atmosphere in the kiln highly poisonous. Therefore all work in the kiln should be preceded by thorough ventilation.

Sawdust levels at sawmill B were determined with personal sampling pumps. The values in table 5 are mean values of exposure measurements during 3 days. It is evident from table 5 that the chlorophenol content in the sawdust decreases rapidly beyond the trimming position. The same general trend can be observed in tables 2 and 3. Most of the chlorophenolcontaminated dust is probably emitted when the wood is transferred from the tilt to the one-piece-feeder line (see fig. 7). The problems associated with the chlorophenol-contaminated dust could therefore be solved with proper ventilation.

\section{ACKNOWLEDGMENTS}

The authors are indebted to Dr. K. Andersson and Mr. $\AA$ Norström, who synthesized some of the standards.

Financial support to this work was given by the Swedish Work Health Fund and this support is gratefully acknowledged.

\section{REFERENCES}

1. BAUGMAN, R. and MESELSON, M. An analytical method for detecting TCDD (Dioxin): Levels of TCDD in samples from Vietnam. Environ. health perspect. 5 (1973) $27-35$.

2. BUSER, H.-R. Analysis of polychlorinated dibenzo-p-dioxins and dibenzofurans in chlorinated phenols by mass fragmentography. J. chromatogr. 107 (1975) 295-310.

3. CROW, K. D. Chloracne: A critical review including a comparison of two series of cases of acne from chlornaphtalene and pitch fumes. Trans. st. johns hosp. dermatol. soc. 56 (1970) 79-99.

4. FIRESTONE, D., RESS, J., BROWN, N. L., BARRON, R. P. and DAMICO, J. N. Determination of polychlorodibenzo- $p$-dioxins and related compounds in commercial chlorophenols. J. assoc. off. anal. chem. 55 (1972) 85-92.

5. GOLDMANN, P. J. Schwerste akute Chloracne durch Trichlorphenol-Zersetzungs sprodukte. Arbeitsmed. Sozialmed. Arbeitshyg. 7 (1972) 12-18.

6. HUSSEIN, S., EHRENBERG, L., LÖFROTH, G. and GEJVALL, T. Mutagenic effects of TCDD on bacterial systems. Ambio 1 (1972) 32-33.

7. JENSEN, S. and RENBERG, L. Contaminants in pentachlorophenol: Chlorinated dioxins and predioxins (chlorinated hydroxy-diphenylethers). Ambio 1 (1972) 6265.

8. JONES, E. L. and KRIZEK, H. A. A technic for testing acnegenic potency in rabbits, applied to the potent acnegen $2,3,7$, 8-tetrachlorodibenzo-p-dioxin. $J$. invest. dermatol. 39 (1962) 511-518.

9. KIMBROUGH, R. D. The toxicity of polychlorinated polycyclic compounds and related chemicals. Crit. rev. toxicol. 1974: $445-498$.

10. KIMMIG, J. and SCHULZ, K. H. Berufliche Akne (sog. Chlorakne) durch chlorierte aromatische Zyklische Äther. Dermatologica 115 (1957) 540-546.

11. LEVIN, J.-O. Kemiska riskmoment i sågverksindustrin. Arsredogörelse, Arbetarskyddsfondens projekt 74/102 (1975).

12. MENON, J. A. Tropical hazards associated with the use of pentachlorophenol. $B r$. med. $j$. (1958) 1156-1158.

13. NEUBERT, D. and DILLMAN, I. Embryotoxic effects in mice treated with $2,4,5$ trichlorophenoxyacetic acid and 2,3,7,8tetrachlorodibenzo-p-dioxin. Arch. pharmacol. 272 (1972) 243-264.

14. NILSSON, C.-A., ANDERSSON, K., RAPPE, C. and WESTERMARK, S.-O. Chromatographic evidence for the formation of chlorodioxins from chloro-2-phenoxyphenols. J. chromatogr. 96 (1974) 137-147.

15. NILSSON, C.-A. and RENBERG, L. Further studies on impurities in chlorophenols. J. chromatogr. 89 (1974) 325-333.

16. NORSTRÖM, A., ANDERSSON, K. and RAPPE, C. Formation of chlorodibenzofurans by irridation of chlorinated diphenyl ethers. Chemosphere (1976): 1, 21-24.

17. PLIMMER, J. R. Technical pentachlorophenol: Origin and analysis of base-insoluble contaminants. Environ. health perspect. 5 (1973) 41-48.

18. RAPPE, C. and NILSSON, C.-A. An artefact in the gas chromatographic determination of impurities in pentachlorophenol. J. chromatogr. 67 (1972) 247-253. 
19. SCHWETZ, B. A., NORRIS, J. M., SPARSCHU, G. L., ROWE, V. K., GEHRING, P. J., EMERSON, J. L. and GERBIG, C. G. Toxicology of chlorinated dibenzo-p-dioxins. Adv. chem. ser. 120 (1973) 55-69.

20. SPARSCHU, G. L., DUNN, F. L. and ROWE, V. K. Study of the teratogenecity of 2,3,7,8-tetrachlorodibenzo-p-dioxin in the rat. Food cosmet. toxicol. 9 (1971) 405-412.

21. TAYLOR, J. S. Chloracne - A continuing problem. Cutis 13 (1974) 585-591.

22. TRUHAUT, R. L'EPEE, P. and BOUSSEMART, E. Recherches sur la toxicologie du pentachlorophénol: II. Intoxications professionnelles dans l'industrie du bois. Observations de deux cas mortels. Arch. mal. prof. med. trav. secur. soc. 13 (1952) $567-569$.

Received for publication: 1976-01-15
23. VOS, J. G., KOEMAN, J. H., VAN DER MAAS, H. L., TEN NOEVER DE BRAUW, M. C. and DE VOS, R. H. Identification and toxicological evaluation of chlorinated dibenzofuran and chlorinated naphthalene in two commercial polychlorinated biphenyls. Food cosmet. toxicol. 8 (1970) 625633.

24. VOS, J. G. and MOORE, J. A. Supression of cellular immunity in rats and mice by maternal treatment with 2,3,7,8-tetrachlorodibenzo-p-dioxin. Int. arch. allergy appl. immunol. 47 (1974) 777-794.

25. ZITKO, V. and CHOI, P. M. K. Oral toxicity of chlorinated dibenzofurans to juvenile Atlantic salmon. Bull. environ. contam. toxicol. 10 (1973) 120-122. 